\title{
Analysis of Impulse Control Disorders (ICDs) and Factors Associated with Their Development in a Parkinson's Disease Population
}

\author{
Mauricio Iván García-Rubio ${ }^{1}$, María Elisa Otero-Cerdeira ${ }^{1}$, Christian Gabriel Toledo-Lozano ${ }^{2}{ }^{\mathbb{B}}$, \\ Sofía Lizeth Alcaraz-Estrada ${ }^{3}$, Juan Antonio Suárez-Cuenca ${ }^{2}$, Ramón Mauricio Coral-Vázquez ${ }^{4}$, \\ Paul Mondragón-Terán ${ }^{5}$, Juan Antonio Pineda-Juárez ${ }^{5}$, Luis Fernando Díaz-López ${ }^{2}$ and Silvia García ${ }^{2, *(1)}$
}

check for

updates

Citation: García-Rubio, M.I.; Otero-Cerdeira, M.E.; Toledo-Lozano, C.G.; Alcaraz-Estrada, S.L.; Suárez-Cuenca, J.A.; Coral-Vázquez, R.M.; Mondragón-Terán, P.;

Pineda-Juárez, J.A.; Díaz-López, L.F.; García, S. Analysis of Impulse Control Disorders (ICDs) and Factors Associated with Their Development in a Parkinson's Disease Population. Healthcare 2021, 9, 1263. https: / / doi.org/10.3390/healthcare9101263

Received: 11 June 2021

Accepted: 21 September 2021

Published: 24 September 2021

Publisher's Note: MDPI stays neutral with regard to jurisdictional claims in published maps and institutional affiliations.

Copyright: (c) 2021 by the authors. Licensee MDPI, Basel, Switzerland. This article is an open access article distributed under the terms and conditions of the Creative Commons Attribution (CC BY) license (https:/ / creativecommons.org/licenses/by/ $4.0 /)$.
1 Movement Disorders \& Neuroscience Unit, (UTMON) Hospital Español, Ciudad de México 11520, Mexico; mauricio.garcia@utmon.com.mx (M.I.G.-R.); neurotm@utmon.com.mx (M.E.O.-C.)

2 Clinical Research Department, Centro Médico Nacional "20 de Noviembre", Ciudad de México 03229, Mexico; drchristiantoledo@gmail.com (C.G.T.-L.); suarej05@gmail.com (J.A.S.-C.); luislong_1805@hotmail.com (L.F.D.-L.)

3 Genomic Medicine Division, Centro Médico Nacional “20 de Noviembre”, Ciudad de México 03229, Mexico; sofializeth@gmail.com

4 Sección de Estudios de Posgrado e Investigación, Escuela Superior de Medicina, Instituto Politécnico Nacional, Ciudad de Mexico 11340, Mexico; rcoral@ipn.mx

5 Research Coordination Centro Médico Nacional "20 de Noviembre", ISSSTE México City, Ciudad de México 03229, Mexico; paul.mondragon@issste.gob.mx (P.M.-T.); juan.pineda@issste.gob.mx (J.A.P.-J.)

* Correspondence: rolasil@yahoo.com.mx; Tel.: +52-5554377491

\begin{abstract}
Parkinson's Disease (PD) is a neurodegenerative disease in which non-motor symptoms may appear before motor phenomena, which include Impulse Control Disorders (ICDs). The objective of this study is to identify factors associated with the development of ICDs in PD. An analytical, cross-sectional study was conducted using clinical records from patients diagnosed with PD, both genders, from 40 to 80 years old. Clinical and demographic data were collected: 181 patients were recruited; 80 of them showed PD and ICDs, and they constituted the study group, whereas 101 patients with PD without ICDs constituted the control reference group. The duration of PD was longer in the group with ICDs $(p<0.008)$, and all patients showed at least one ICD: binge eating $(61.29 \%)$, compulsive shopping $(48.75 \%)$, hypersexuality $(23.75 \%)$, gambling behavior $(8.75 \%)$, and punding $(3.75 \%)$. After logistic regression analysis, only the use of dopamine agonists remained associated with ICDs $(p<0.001)$, and the tremorgenic form was suggested to be a protective factor $(p<0.001)$. Positive associations were observed between the rigid-akinetic form and compulsive shopping $(p<0.007)$, between male and hypersexuality $(p<0.018)$, and between dopamine agonists and compulsive shopping $(p<0.004)$, and negative associations were observed between motor fluctuations and compulsive shopping $(p<0.031)$, between Deep Brain Stimulation and binge eating $(p<0.046)$, and between levodopa consumption and binge eating $(p<0.045)$. Binge eating, compulsive shopping, and hypersexuality were the most frequent ICDs. Complex forms and motor complications of PD were associated with the development of ICDs.
\end{abstract}

Keywords: Parkinson's disease; impulse control disorders; associated factors

\section{Introduction}

Parkinson's disease (PD) is the second most frequent neurodegenerative process, only after Alzheimer's disease [1] and affects more than 5 million people around the world [2]. Its etiology has been attributed to genetic and environmental factors. The pathogenic role of alpha-synuclein protein plays a key role in the current understanding of PD [3,4]. PD affects all populations, though it is more common in Caucasian males in Europe and North 
America, while African Americans and other races are less likely to have PD [2,5]. The prevalence of $\mathrm{PD}$ in the general population is $0.3 \%$ and may affect $1-2 \%$ of patients older than 60 years old and up to $4 \%$ of patients older than 85 , while this prevalence is expected to double by 2030 [6].

Motor symptoms occur after 5 to 10 years from the onset of dopaminergic neuronal loss, and they are still the milestone of PD diagnostic criteria, with bradykinesia, rigidity, tremor, and loss of postural reflexes being clinical manifestations that sustained PD diagnosis [7]. Consequently, the late appearance of motor symptoms delays clinical diagnosis [8].

Non-Motor Symptoms of PD (NMSPD) appear years before motor phenomena and could be the key to early diagnosis. NMSPD are diverse and range from sensory phenomena (hyposmia and anosmia) to behavior disorders, among others. NMSPD include neuropsychiatric symptoms such as depressive disorders (4 to $70 \%$ ), cognitive decline $(32 \%)$, excessive daytime drowsiness (51\%), Rapid Eye Movement sleep disturbances (27 to 32\%), and hallucinations and visual illusions (40\%) [9-14]. More than $60 \%$ of PD patients have one or more psychiatric symptoms, which can precede the onset of motor symptoms, even by years. Some symptoms, such as depression or anxiety, are independent of treatment, while others, such as psychosis and Impulse Control Disorders (ICDs), are triggered by dopamine therapy $[15,16]$.

One group of neuropsychiatric symptoms include ICDs, which are characterized by dysfunctions, in both emotional and behavioral regulation, that share the inability to resist an urge or temptation to carry out actions that result as being harmful for themselves or others $[17,18]$. Understanding risk factors and how they link to ICDs in PD could allow for the early identification of populations at risk and/or to design therapies leading to better care and to increased quality of life.

Potential risk factors for the onset of ICDs in PD are personality traits or impulsivity, depression, male gender, substance abuse, younger age, an earlier PD onset age, concurrent use of levodopa and dopamine agonists (DAAs), longer duration of DA treatment, being single, history of ICDs before PD, current smoking, more formal education, family history of substance abuse or ICDs, preserved executive functions, increased aggressiveness, irritability, disinhibition, and eating disorders $[15,19]$.

It is not currently clear whether certain ethnicities are more prone to ICDs in PD, but there could be differences in the most common impulsive behaviors of different regions that are culturally driven. Previous studies have found PD-related ICDs in various populations: $60 \%$ reported hypersexuality (Brazil, Finland, and Israel), $>50 \%$ described punding (Turkey, Mexico, and India), 57\% reported compulsive shopping (Brazil), and $\sim 40 \%$ reported gambling (Italy and the USA) [20].

PD-related ICDs have been associated with stereotyped behavior or punding in $13-26 \%$ of the cases [14]. Both manifestations are closely linked to agonist dopamine drug use [21-23]. Within the ICDs, gaming disorders and hypersexuality are more common in males, while binge eating and compulsive shopping are more common in women $[24,25]$. ICDs in any of the subtypes are usually extremely devastating to the patient and their family's quality of life. A summary of the factors in the PD profile is shown in Figure 1.

DAAs (pramipexole, rotigotine, and ropinirole) are an important group of drugs for PD treatment $[26,27]$. Some authors propose that ICDs may be caused by an impaired capacity of the orbitofrontal cortex (OFC) to guide behavior [28], and that has been attributed to neuronal dopaminergic degeneration, facilitating ICD occurrence in dopamine replacement therapies [29]. 

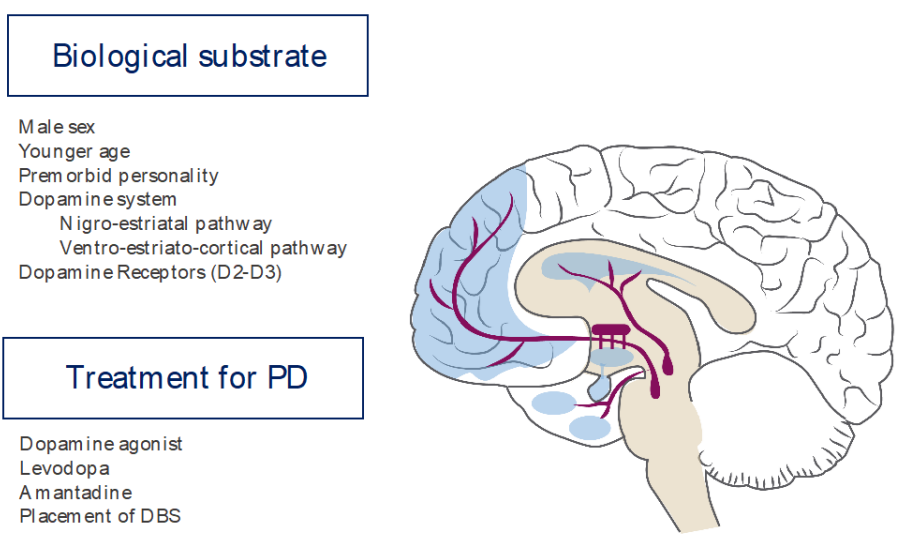

Genetic predisposition

DRD 3 p.Ser 9Gly (rs6280) heter ozygous variant CT genotype DRD $1 \mathrm{rs} 4867798$ DRD 1 rs4532 DRD 2/AN KK1 rs1800497 \& GRIN 2B rs7301328 OPRK1, HTR2A, \& DDC genes

$\begin{aligned} & \text { Profile of Parkinson } \\ & \text { Disease }\end{aligned}$
Early onset
Tremorgen ic, rigid-akinetic or m ix
form
M otor com plications
Neu ropsychiatry complications
Cognitive impairm ent
PD duration

Figure 1. Risk factors for ICDs in patients with PD.

In Mexico, PD is a growing health challenge in which there is not enough information about ICD frequency and the factors involved. The goal of this research is to identify factors associated with ICD development in PD patients treated in Mexico City.

\section{Materials and Methods}

An analytical, cross-sectional (case-control) study was conducted using the clinical records of patients from the Movement Disorder \& Neuroscience Unit (UTMON) of the "Hospital Español de México" in Mexico City. The ethics committee approved the study.

Patients with PD diagnosis, according to the United Kingdom Parkinson's Disease Society Brain Bank (UK-PDSBB), were recruited. The sampling was non-probabilistic for convenience. The inclusion criteria included patients of both sex were between 40 and 80 years old, and how did not have a psychiatric history before PD diagnosis.

Patients were divided into two groups: the ICD Group "PD with ICDs", who were diagnosed by a certificated psychiatrist according to DSM- 5 criteria, and the Non-ICD Group, "PD without ICDs". Patients with dementia were excluded, as were those with non-congruent data in clinical records. Information about both groups was obtained from the same source, which is the Clinical Files Department of "Hospital Español de México". The cases were selected consecutively, and the controls were matched by age and gender.

Clinical and demographic data regarding the onset and evolution of PD was collected. In both groups, the type of ICD and specific psychiatric symptoms were documented, as were the time of application of antiparkinsonian-type drugs, their dose, and their time of use; the use of Deep Brain Stimulation (DBS); and the UPDRS score.

Association analyses were performed with clinical-demographic data, therapy variables, and ICD presence. A $t$-test was used to compare baseline characteristics. Bonferroni correction was used as a method to adjust p-values due to multiple comparisons in post hoc analysis. Logistic regression analyses were performed and expressed as Odds Ratio and 95\% confidence intervals. The Statistical Package for the Social Sciences (SPSS) software v.24 (IBM, Armonk, NY, USA) was used for statistical analysis.

\section{Results}

One hundred and eighty-one patients with PD were recruited. The study group (ICD Group) showed PD and concomitant ICDs $(n=80)$. For comparison, a control reference (Non-ICD Group) was included $(n=101)$.

The demographic data are comparable in both groups (Table 1); however, the PD duration as significantly longer in the ICD Group. Bonferroni correction was used as a method to adjust $p$-values due to multiple comparisons in a post hoc analysis. 
Table 1. Characteristic demography of patients in each group.

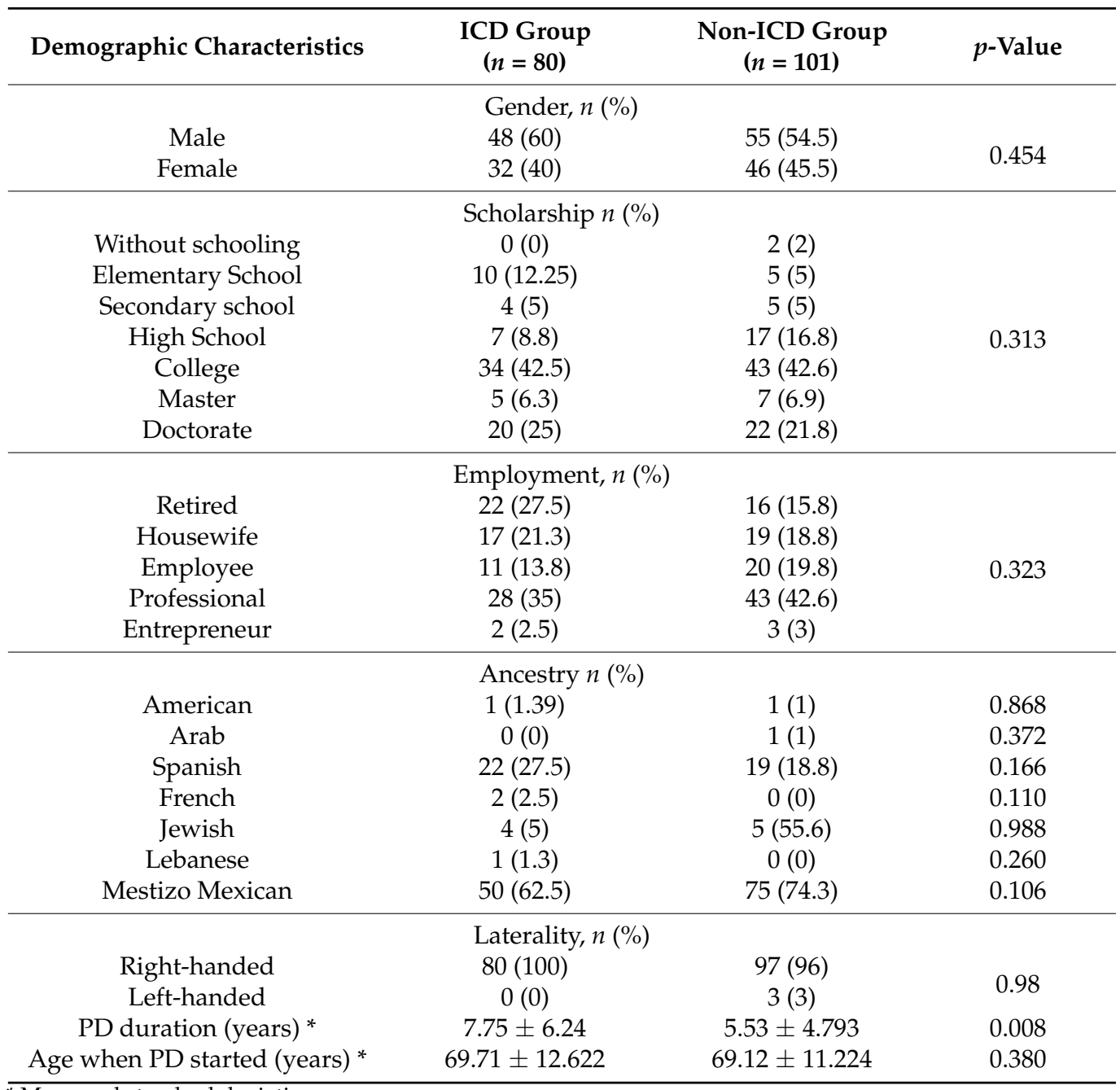

* Mean and standard deviation.

According to the outcome ICDs (Table 2), it was remarkable that the tremorgenic type of PD was more common in the Non-ICD Group $(p<0.0001)$; the rigid-akinetic form was more frequent in the ICD Group $(p<0.005)$. As expected, the high prevalence of tremorgenic manifestations was negatively associated with the development of ICDs $(p<0.006)$, while a high prevalence of rigidity positively was associated with ICDs $(p<0.005)$.

Regarding the doses of dopamine replacement therapy used (levodopa $p<0.166$, pramipexole $p<0.232$, rotigotine $p<0.262$, and rasagiline $p<0.041$ ), no statistically significant difference was found, except for the doses of rasagiline.

The logistic regression analysis evidenced that only DAAs use was significantly associated with ICD development $(p<0.001)$. PD duration showed a non-significant tendency $(p<0.067)$. The tremorgenic form was suggested as a protective factor $(p<0.001)$. In the same analysis, the main non-motor symptoms (depression $(p<1.000)$, anxiety $(p<0.515)$, chronic pain $(p<0.335)$, REM sleep disturbances $(p<1.000)$, hallucinations $(p<1.000)$, and hyposmia $(p<0.620))$ were not associated with ICDs in our study population. 
Table 2. Clinical characteristic of both groups and their association with the outcome Impulse Control Disorders (ICDs).

\begin{tabular}{|c|c|c|c|c|c|}
\hline Clinical Characteristics & $\begin{array}{l}\text { ICD Group } \\
\quad(n=80)\end{array}$ & $\begin{array}{l}\text { Non-ICD Group } \\
\quad(n=101)\end{array}$ & $p$-Value & OR & $95 \% \mathrm{CI}$ \\
\hline \multicolumn{6}{|c|}{ PD clinical predominant type, $n(\%)$} \\
\hline Tremorgenic form & $23(28.75)$ & $39(38.61$ & 0.0001 & 0.548 & $0.399-0.803$ \\
\hline Rigid-akinetic form & $33(41.3)$ & $21(20.8)$ & 0.005 & 1.610 & $1.188-2.200$ \\
\hline Mixed form & $6(7.5)$ & $2(1.98)$ & 0.141 & 1.753 & $1.134-2.711$ \\
\hline \multicolumn{6}{|c|}{ Symptoms $n(\%)$ : } \\
\hline Tremor & 47 (58.75) & $79(78.21)$ & 0.006 & 0.622 & $0.455-0.850$ \\
\hline Bradykinesia & $78(97.5)$ & $100(99)$ & 0.584 & 0.657 & $0.290-1.488$ \\
\hline Rigid & $45(56.25)$ & $41(40.59)$ & 0.051 & 1.420 & $1.019-1.979$ \\
\hline Postural instability & $9(11.25)$ & $13(12.87)$ & 0.821 & 0.916 & $0.539-1.558$ \\
\hline \multicolumn{6}{|c|}{ Medical history $n(\%)$} \\
\hline Arterial hypertension & $57(71.25)$ & $37(36.63)$ & 0.181 & 1.199 & $0.921-1.561$ \\
\hline Mellitus diabetes & $13(1.25$ & $7(6.93)$ & 0.477 & 1.189 & $0.837-1.689$ \\
\hline Dyslipidemia & $18(22.5)$ & $8(7.9)$ & 0.200 & 1.293 & $0.961-1-737$ \\
\hline Hypothyroidism & $12(15)$ & $4(3.9)$ & 0.121 & 1.390 & $1.014-1.907$ \\
\hline \multicolumn{6}{|c|}{ Dopamine replacement therapy $n(\%)$} \\
\hline Levodopa & $74(92.5)$ & $85(84.2)$ & 0.110 & 1.706 & $0.845-3.445$ \\
\hline Dopamine Agonists & $72(90)$ & $54(53.5)$ & 0.0001 & 3.929 & $2.034-7.587$ \\
\hline MAOI & $53(66.3)$ & $66(65.3)$ & 1.000 & 1.028 & $0.723-1.461$ \\
\hline COMI & $9(11.3)$ & $5(5)$ & 0.161 & 1.512 & $0.985-2.321$ \\
\hline Motor fluctuations $n(\%)$ & $37(46.3)$ & $31(30.7)$ & 0.031 & 1.469 & $1.066-2.023$ \\
\hline Dyskinesia $n(\%)$ & $29(36.3)$ & $21(20.8)$ & 0.029 & 1.490 & $1.083-2-049$ \\
\hline DBS $n(\%)$ & $13(16.3)$ & $6(5.9)$ & 0.029 & 1.654 & $1.159-2.362$ \\
\hline Non-motor symptoms $n(\%)$ & $n=17$ & $n=17$ & $p$-Value & OR & $95 \% \mathrm{CI}$ \\
\hline Depression & $1(5.8)$ & $1(5.8)$ & 1.000 & 1.500 & $0.315-7.137$ \\
\hline Anxiety & $2(11.7)$ & $1(5.8)$ & 0.515 & 2.333 & $0.738-7.381$ \\
\hline Chronic pain & $2(11.7)$ & $7(41.1)$ & 0.335 & 0.444 & $0.109-1.811$ \\
\hline REM sleep disturbances & $3(17.6)$ & $5(29.4)$ & 1.000 & 1.125 & $0.311-4.071$ \\
\hline Hallucinations & $1(5.8)$ & $1(5.8)$ & 1.000 & 1.500 & $3.15-7.137$ \\
\hline Hyposmia & $2(11.7)$ & $6(35.2)$ & 0.620 & 0.563 & $0.138-2.293$ \\
\hline \multicolumn{6}{|c|}{ Mean and standard deviation } \\
\hline UPDRS & $23.20 \pm 6.028$ & $23.51 \pm 6.307$ & 0.734 & & \\
\hline Age at PD Diagnosis & $61.96 \pm 13.386$ & $63.58 \pm 11.385$ & 0.380 & & \\
\hline PD duration (years) & $7.75 \pm 6.249$ & $5.53 \pm 4.796$ & 0.008 & & \\
\hline \multicolumn{6}{|c|}{ Doses (mg/day) } \\
\hline Levodopa & $568.019 \pm 383.459$ & $466.361 \pm 541.84$ & 0.166 & & \\
\hline Pramipexole & $1.140 \pm 1.098$ & $0.952 \pm 1.001$ & 0.232 & & \\
\hline Rotigotine & $5.90 \pm 1.77$ & $5.09 \pm 1.375$ & 0.262 & & \\
\hline Ropirinol & $0.19 \pm 1.68$ & 0 & & & \\
\hline Rasagiline & $0.4019 \pm 0.510$ & $0.2575 \pm 0.428$ & 0.041 & & \\
\hline
\end{tabular}

CI: confidence interval; COMI: catechol-O-methyltransferase inhibitors; DA: dopamine agonists; ICD: Impulse Control Disorders; MAOI: monoamine oxidase inhibitors; OR: odds ratio; UPDRS: Unified Parkinson's Disease Rating Scale.

Five clinical events were more frequent and were associated with ICDs: motor fluctuations $(p<0.031)$; dyskinesias $(p<0.029)$, DAAs consumption $(p<0.0001)$, Parkinson's disease duration (years), and DBS placement $(p<0.029)$. Surprisingly, the ICD Group consumed the highest doses of rasagiline. Finally, the Hoehn and Yahr Scale score was not associated with ICDs (Figure 2). 


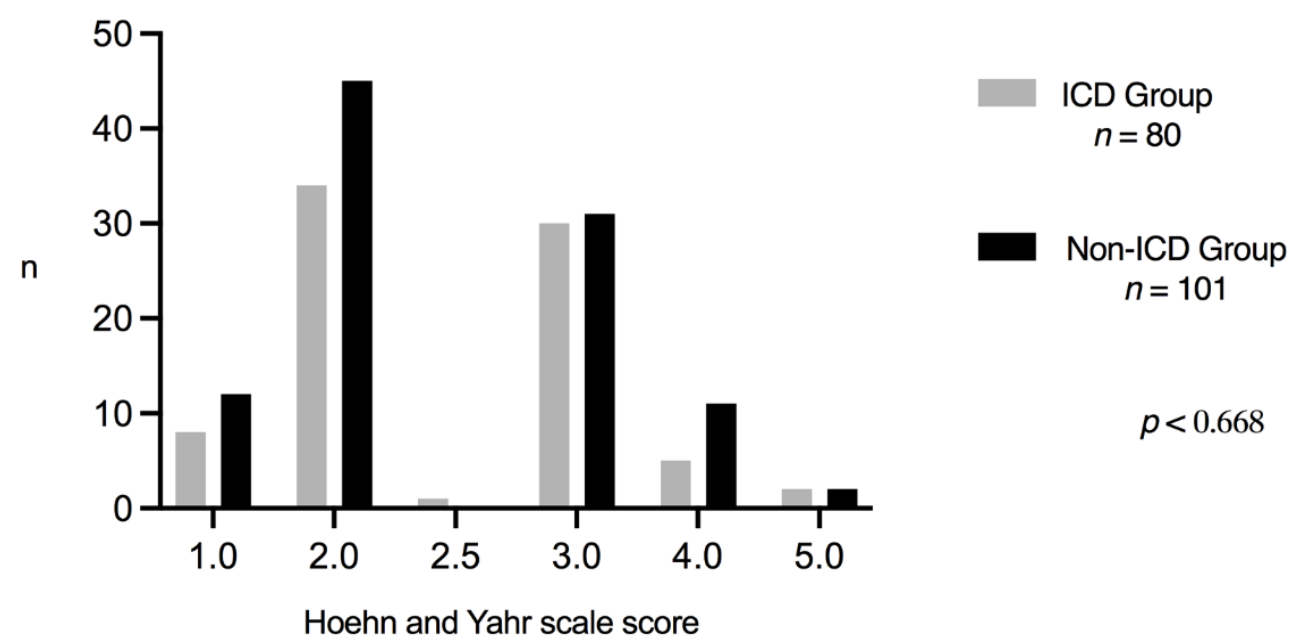

Figure 2. Hoehn and Yahr comparison.

Regarding clinical manifestations, the ICD Group was characterized by the following profile: binge eating was highly prevalent $(n=47,58.8 \%)$, followed by compulsive shopping $(n=22,21.4 \%)$, hypersexuality $(n=19,18.4 \%)$, gambling disorder $(n=3,2.9 \%)$, and punding $(n=4,5.1 \%)$. According to the number of ICDs, one ICD type was developed in 49 out of 80 cases $(61.25 \%)$ : binge eating disorder $(n=22,27.5 \%)$, a compulsive shopping disorder $(n=15,18.75 \%)$, hypersexuality $(n=8,10 \%)$, gambling disorder $(n=2,2.5 \%)$, and punding disorder $(n=2,2.5 \%)$. Cases with 2 ICDs occurred in 23 out of 80 cases $(28.75 \%)$, as follows: binge eating disorder and compulsive shopping disorders $(n=12$, $15 \%)$, hypersexuality and binge eating disorder $(n=5,6.25 \%)$, binge eating disorder and gambling disorder $(n=2,2.5 \%)$, compulsive shopping disorder and hypersexuality $(n=2,2.5 \%)$, and gambling disorder and compulsive shopping disorder $(n=2,2.5 \%)$. Only eight patients $(10 \%)$ developed three ICDs types; six $(7.5 \%)$ developed binge eating disorder, hypersexuality, and compulsive shopping disorder; one patient (1.25\%) developed hypersexuality, compulsive shopping disorder, and punding disorder; and one (1.25\%) developed hypersexuality, compulsive shopping, and gambling disorder.

The following variables were positively associated: male and hypersexuality; mixed form and gambling behavior; rigid-akinetic form and compulsive shopping, DAAs and compulsive shopping; DAAs and binge eating; motor fluctuations and compulsive shopping; and DBS and binge eating (Table 3). In contrast, negative associations were found between DAAs and hypersexuality, levodopa consumption and binge eating, and tremorgenic form and compulsive shopping.

After adjusting for potential confounding variables, logistic regression showed independent associations between the rigid-akinetic form and compulsive shopping; between the genders male and female, and hypersexuality; between levodopa consumption and binge eating; between DAAs and compulsive shopping; between DAAs and hypersexuality; between DAAs and binge eating; between motor fluctuations and compulsive shopping; and between DBS and binge eating (Table 4).

Additionally, age at PD diagnosis in the ICD Group with hypersexuality $(58.12 \pm 14.64$ years old) was younger than in the Non-ICD Group $(63.55 \pm 11.820)(p<0.05)$. The subgroups with compulsive shopping and binge eating also showed differences $(59.28 \pm 14.74$ vs. $63.85 \pm 11.403, p<0.04$, and $7.96 \pm 6.376$ vs. $6.01 \pm 5.202, p<0.039$, respectively); however, no significant association was further observed. 
Table 3. Clinical factors, and their association with a spectrum of ICDs.

\begin{tabular}{|c|c|c|c|c|c|c|c|c|c|c|}
\hline $\begin{array}{l}\text { Clinical } \\
\text { Factors }\end{array}$ & $\begin{array}{c}\text { Gambling } \\
\quad n=7\end{array}$ & $p$ & $\begin{array}{l}\text { Punding } \\
\quad n=3\end{array}$ & $p$ & $\begin{array}{c}\text { Compulsive } \\
\text { Shopping } \\
n=39\end{array}$ & $p$ & $\begin{array}{l}\text { Hypersexuality } \\
\qquad n=23\end{array}$ & $p$ & $\begin{array}{l}\text { Binge } \\
\text { Eating } \\
n=47\end{array}$ & $p$ \\
\hline Gender (M/F) & $3 / 4$ & 0.466 & $2 / 1$ & 1 & $22 / 17$ & 1 & $19 / 4$ & 0.012 & $28 / 19$ & 0.733 \\
\hline $\begin{array}{l}\text { Mexican } \\
\text { Ancestry }\end{array}$ & $3 / 7$ & 0.134 & $2 / 3$ & 0.673 & $29 / 39$ & 0.273 & $16 / 23$ & 0.582 & $29 / 47$ & 0.137 \\
\hline $\begin{array}{l}\text { Tremorgenic } \\
\text { form }\end{array}$ & $4 / 7$ & 0.692 & $1 / 3$ & 0.270 & $15 / 39$ & 0.0001 & $15 / 23$ & 1 & $26 / 47$ & 0.107 \\
\hline $\begin{array}{l}\text { Rigid-akinetic } \\
\text { form }\end{array}$ & $1 / 7$ & 0.675 & $1 / 3$ & 1 & $20 / 39$ & 0.001 & $7 / 23$ & 1 & $17 / 47$ & 0.265 \\
\hline Mix form & $2 / 7$ & 0.032 & $1 / 3$ & 0.127 & $3 / 39$ & 0.372 & $1 / 23$ & 1 & $3 / 47$ & 0.430 \\
\hline $\begin{array}{l}\text { Levodopa } \\
\text { consumption }\end{array}$ & $7 / 7$ & 0.397 & $3 / 3$ & 0.676 & $36 / 39$ & 0.254 & $20 / 23$ & 0.554 & $46 / 47$ & 0.008 \\
\hline DAAs & $7 / 7$ & 0.103 & $3 / 3$ & 0.335 & $38 / 39$ & 0.0001 & $20 / 23$ & 0.055 & $41 / 47$ & 0.002 \\
\hline MAOIs & $5 / 7$ & 1 & $2 / 3$ & 1 & $28 / 39$ & 0.565 & $17 / 23$ & 0.486 & $30 / 47$ & 0.857 \\
\hline $\begin{array}{c}\text { Motor } \\
\text { Fluctuations }\end{array}$ & $2 / 7$ & 0.710 & $1 / 3$ & 1 & $22 / 39$ & 0.010 & $10 / 23$ & 0.648 & $23 / 47$ & 0.083 \\
\hline Dyskinesias & $2 / 7$ & 1 & $1 / 3$ & 1 & $15 / 39$ & 0.106 & $7 / 23$ & 0.804 & $18 / 47$ & 0.087 \\
\hline $\begin{array}{l}\text { Postural } \\
\text { instability }\end{array}$ & $2 / 7$ & 0.203 & $0 / 3$ & 1 & $2 / 39$ & 0.170 & $4 / 23$ & 0.491 & $5 / 47$ & 0.801 \\
\hline DBS & $0 / 7$ & 1 & $0 / 3$ & 1 & $7 / 39$ & 0.135 & $5 / 23$ & 0.072 & $9 / 47$ & 0.049 \\
\hline
\end{tabular}

DAAs: dopamine agonists; DBS: deep brain stimulation; MAOI: monoamine oxidase inhibitors; M: male; F: female.

Table 4. Clinical and demographic factors, and their association with a spectrum of ICDs.

\begin{tabular}{|c|c|c|c|c|c|}
\hline $\begin{array}{c}\text { Clinical and Demographic } \\
\text { Factors }\end{array}$ & $\mathbf{N}$ & $p$ Value & OR & $95 \%$ CI & Logistic Regression * \\
\hline $\begin{array}{l}\text { Mixed form/gambling } \\
\text { disorders }\end{array}$ & $2 / 7$ & 0.032 & 8.65 & $1.972-37.951$ & - \\
\hline $\begin{array}{c}\text { Rigid-akinetic } \\
\text { form/compulsive shopping }\end{array}$ & $20 / 39$ & 0.001 & 2.542 & $1.481-4.363$ & 0.007 \\
\hline Male gender/hypersexuality & $9 / 4$ & 0.012 & 3.597 & $1.275-10.150$ & 0.018 \\
\hline $\begin{array}{c}\text { Levodopa } \\
\text { consumption/binge eating }\end{array}$ & $46 / 47$ & 0.008 & 0.745 & $0.651-0.852$ & 0.045 \\
\hline DAAs/compulsive shopping & $38 / 39$ & 0.0021 & 16.587 & $2.336-117.777$ & 0.004 \\
\hline DAAs/hypersexuality & $20 / 23$ & 0.056 & 0.890 & $0.806-0.982$ & 0.095 \\
\hline DAAs/binge eating & $41 / 47$ & 0.002 & 2.983 & $1.346-6.612$ & - \\
\hline $\begin{array}{c}\text { Motor } \\
\text { fluctuations/compulsive } \\
\text { shopping }\end{array}$ & $22 / 39$ & 0.010 & 2.101 & $1.203-3.668$ & 0.031 \\
\hline $\begin{array}{c}\text { Tremorgenic } \\
\text { form/compulsive shopping }\end{array}$ & $15 / 39$ & 0.0001 & 0.326 & $0.185-0.574$ & - \\
\hline DBS/binge eating & $38 / 47$ & 0.049 & 0.495 & $0.286-0.858$ & 0.046 \\
\hline
\end{tabular}

CI: confidence interval; DAAs: dopamine agonists; DBS: deep brain stimulation, OR: odds ratio. * Reference group: Non-ICD Group.

\section{Discussion}

ICDs are a very complex entity in the PD context and need to be considered a multifactorial alteration encompassing treatment drugs for PD and other disease-related factors [17].

In the Diagnostic and Statistical Manual of Mental Disorders, Fifth Edition (DSM-5), ICDs are called "Disruptive, Impulse Control and Behavior Disorders"; these symptoms have a common denominator of an inability to resist an impulse or temptation to perform 
an act that is harmful [26,30], experiencing pleasure, gratification, or release of tension after performing the action. ICDs reported in PD patients include compulsive shopping, gambling, hypersexuality, obsessing over hobbies, punding, binge eating, and compulsive medication use [31,32].

NMSPDs such as depression, anxiety, REM sleep disturbances, aggressiveness, chronic pain, or hyposmia have been described as being closely related to the development of ICDs [17]. In the present study population, such NMSPDs did not show particular differences between comparison groups, perhaps because these disorders are common in PD but do not necessarily predict the appearance of ICDs.

One of the main findings of this study was the association between rigid-akinetic, tremorgenic forms with ICDs. Dopamine is involved in both PD and ICDs and is a very important substance in the normal brain-specific function for the control of motor function, motivation, and learning. Although nigrostriatal denervation was proposed as an etiology for ICDs, only a few patients with PD develop them. The nigrostriatal pathway is involved in motor function and influences the mesocorticolimbic pathway (reward system) and the tuberoinfundibular pathway, which influences the secretion of prolactin [26]. The neuro-degenerative processes of PD affect several pathways responsible for modulating the reward system, positive reinforcement, motivation, inhibitory control, and decision making implicated in impulse control [24]. Despite the theoretically limiting actions in certain regions of the Central Nervous System of DAAs, it habitually affects different areas of the brain in PD patients. For more than two decades, ICD cases have been associated with DAAs consumption [33,34] and they were considered iatrogenic, so symptomatology began after using DAAs and disappeared when it was stopped [26]. Elucidating how biological events of the disease interact with the effect of drugs for general ICDs is a challenge. There are researchers who consider that impulsivity is a PD symptom $[35,36]$. However, DAAs influence hyperactivation of the reward system and reduce neuronal activity related to impulse control processes and response inhibition. For the association found between levodopa and binge eating, previous studies have suggested that reward systems may have a role in binge eating. Nonetheless, a direct relationship between the use of levodopa and this ICD [37] has not been established. The association between DAAs and the development of binge eating has been shown in the literature, mainly with pramipexole, but the exact action mechanism is still unknown [38]. Male gender is an independent factor for developing ICDs [39-44] implicated in gambling and hypersexual behavior [45]. In our population, male gender was associated with hypersexuality, but there was no association in females. Other studies have described the presence of hypersexuality in patients treated with levodopa, DAAs, or selegiline [46], but that association was not detected in our study.

Likewise, we found that DBS placement was a risk factor for ICDs as well as the association between DBS and binge eating. Current evidence is scarce and controversial. Some studies have described the association of DBS with the improvement, deterioration, or development of ICDs. However, DBS placement in the subthalamic nucleus has been associated with the development of this ICD subtype [47,48]. Stimulation in this nucleus leads to a decrease in the DAAs dose and translates into a decreased appearance of ICDs [49]. In our study population, 13 out of 19 cases with DBS have ICDs, suggesting that DBS could favor the presence of ICDs, perhaps due to the complex physiology and interactions of nuclei of the base, particularly of the ventral striatum most frequently associated with stimulation of the subthalamic nucleus [49,50].

Another relevant finding was the duration of PD. Previous reports show that younger patients (under 65 years old) with PD or its onset at a younger age is an independent predictor for developing ICDs [24,40,44,51-58]. However, no association of PD duration or age of onset with gambling was detected in the present study. It is possible that more attention is paid to patients with movement, whereas ICDs may be uncovered. Another possibility is that the age of the study population (mean age 60 years old) could constitute a bias selection. Regarding the duration of PD associated with the development of ICDs [35,42,58], there is no general consensus between authors [59]; it is possible that 
more extended degeneration leads to more tissue damage. Consistently, PD diagnosed at a younger age was related with hypersexuality and compulsive disorders, while PD duration was longer in binge eating cases. It was interesting to find a positive association between higher doses of rasagiline and the development of ICDs. There are reports suggesting that rasagiline is a risk factor for ICDs [53,60,61]. Studies specifically designed to confirm this finding are needed. In contrast, DAAs and L-dopa have been involved in ICDs developed in PD patients [23,54,62-68], which is consistent with our results.

An important observation in this research was that the rigid-akinetic form was a risk factor for the presence of ICDs, while the tremorgenic form seems to protect against the presence of ICDs, according to association analyses. It has been documented that patients with greater motor disease complexity and more frequent motor fluctuations have ICDs. Furthermore, PD tremors seem to be strongly related to abnormal activity in the cerebellum receptor of the thalamus gland (ventral intermediate nucleus). Tremors respond to dopaminergic therapy, although it is not clear how the loss of dopamine is related with tremors. Dopamine may have less importance in tremors than in other PD symptoms and is a protective factor for the development of ICDs $[43,45,69,70]$. Based on current scientific evidence, current proposed pathophysiological mechanisms explaining these findings are complex and need future research for a better understanding [49]. A strength of this research is that it included subjects from diverse ethnical origins: American, Arab, Spanish, French, Jewish, Lebanese, and Mexican Mestizo, due to the type of Hospital target population, where Mexican Mestizo was the most common population. There were no significant differences despite ethnical variability, suggesting that ICDs behave similarly between ethnical populations, at least from the ethnical diversity included in the present study.

The limitations of this study are related to the inclusion of patients from a center specialized in the care of PD, which could explain the high prevalence of ICDs in our study and the lack of standardized registries. At the time of this study, there are no validated diagnostic instruments in the Mexican population to identify patients with ICDs. There are no epidemiological or statistical records about ICDs in patients with PD that allow us to establish a comparison with the results of this research in the Mexican population. Furthermore, the authors consider it relevant to replicate the findings in a larger sized sample to establish more precise associations, allowing for comparison with American or European studies. Likewise, it is necessary to carry out prospective studies to generate more solid evidence on the impact of social, cultural, genetic, or environmental factors that influence the development of these disorders in the Mexican population beyond dopamine replacement therapy.

It is important to recognize factors associated with ICDs since they have a significant impact on the quality of life of the patient and their family members. Early detection allows for timely treatment of these disorders to be started and for avoiding consolidation of ICDs.

\section{Conclusions}

In conclusion, the most frequent ICDs observed in this study were binge eating, compulsive shopping, and hypersexuality. The rigid-akinetic form of PD, DAAs use, and motor fluctuations were positively associated with compulsive shopping devolvement; in contrast, the tremorgenic form was a protective factor. Levodopa and DAAs use were associated with binge eating devolvement. DBS placement was a risk factor for general ICDs. In addition, being male and DAAs use were risk factors for hypersexuality devolvement.

Author Contributions: Conceptualization, M.I.G.-R. and M.E.O.-C.; methodology, M.I.G.-R. and M.E.O.-C.; formal analysis, M.I.G.-R., M.E.O.-C., C.G.T.-L., J.A.S.-C., R.M.C.-V., P.M.-T. and S.G.; investigation, M.I.G.-R., M.E.O.-C. and S.G.; writing—original draft preparation, M.I.G.-R., M.E.O.-C., S.L.A.-E., J.A.S.-C., R.M.C.-V. and S.G.; writing-review and editing, M.I.G.-R., M.E.O.-C., C.G.T.-L., S.L.A.-E., P.M.-T., J.A.P.-J., L.F.D.-L. and S.G. All authors have read and agreed to the published version of the manuscript. 
Funding: This research received no external funding.

Institutional Review Board Statement: The study was conducted according to the guidelines of the Declaration of Helsinki and was approved by the Ethics Committee and Research Committee of Hospital Español de Mexico (protocol code EHE 066, date of approval 21 June 2019).

Informed Consent Statement: Patient consent was waived because the data were obtained from medical records with data de-identification.

Data Availability Statement: Datasets analyzed or generated during the study can be requested from the authors.

Conflicts of Interest: The authors declare no conflict of interest.

\section{References}

1. Rizek, P.; Kumar, N.; Jog, M.S. An update on the diagnosis and treatment of Parkinson disease. CMAJ 2016, 188, 1157-1165. [CrossRef] [PubMed]

2. Olanow, C.W.; Stern, M.B.; Sethi, K. The scientific and clinical basis for the treatment of Parkinson disease. Neurology 2009, 72 (Suppl. 4), S1-S136. [CrossRef]

3. Fahn, S. Description of Parkinson's disease as a clinical syndrome. Ann. N. Y. Acad. Sci. 2003, 991, 1-14. [CrossRef]

4. Burré, J.; Sharma, M.; Südhof, T.C. Cell Biology and Pathophysiology of $\alpha$-Synuclein. Cold Spring Harb. Perspect. Med. 2018, 8, a024091. [CrossRef]

5. Dahodwala, N.; Siderowf, A.; Xie, M.; Noll, E.; Stern, M.; Mandell, D.S. Racial differences in the diagnosis of Parkinson's disease. Mov. Disord. 2009, 24, 1200-1205. [CrossRef] [PubMed]

6. Massano, J.; Bhatia, K.P. Clinical approach to Parkinson's disease: Features, diagnosis, and principles of management. Cold Spring Harb. Perspect. Med. 2012, 2, a008870. [CrossRef] [PubMed]

7. Jankovic, J. Parkinson's disease: Clinical features and diagnosis. J. Neurol. Neurosurg. Psychiatry 2008, 79, 368-376. [CrossRef] [PubMed]

8. Arriaga, A.C.; Violante, M.R.; Ordóñez, A.C.; González, L.P.; López-Ruiz, M.; Estrada-Bellmann, I.; Zúñiga-Ramírez, C.; OteroCerdeira, E. Tiempo desde el inicio de los síntomas motores hasta el diagnóstico de enfermedad de Parkinson (EP) en México. Gac. Med. Mex. 2014, 150 (Suppl. 2), 242-247.

9. Sveinbjornsdottir, S. The clinical symptoms of Parkinson's disease. J. Neurochem. 2016, 139 (Suppl. 1), 318-324. [CrossRef] [PubMed]

10. Dickson, D.W. Neuropathology of Parkinson disease. Parkinsonism Relat. Disord. 2018, 46 (Suppl. 1), S30-S33. [CrossRef]

11. Postuma, R.B.; Berg, D.; Stern, M.; Poewe, W.; Olanow, C.W.; Oertel, W.; Obeso, J.; Marek, K.; Litvan, I.; Lang, A.E.; et al. MDS clinical diagnostic criteria for Parkinson's disease. Mov. Disord. 2015, 30, 1591-1601. [CrossRef] [PubMed]

12. Schrag, A.; Horsfall, L.; Walters, K.; Noyce, A.; Petersen, I. Prediagnostic presentations of Parkinson's disease in primary care: A case-control study. Lancet Neurol. 2015, 14, 57-64. [CrossRef]

13. Bronner, G.; Korczyn, A.D. The Role of Sex Therapy in the Management of Patients with Parkinson's Disease. Mov. Disord. Clin. Pract. 2018, 5, 6-13. [CrossRef] [PubMed]

14. Poewe, W. Non-motor symptoms in Parkinson's disease. Eur. J. Neurol. 2008, 15 (Suppl. 1), 14-20. [CrossRef] [PubMed]

15. Sharma, A.; Goyal, V.; Behari, M.; Srivastva, A.; Shukla, G.; Vibha, D. Impulse control disorders and related behaviours (ICD-RBs) in Parkinson's disease patients: Assessment using "Questionnaire for impulsive-compulsive disorders in Parkinson's disease" (QUIP). Ann. Indian Acad. Neurol. 2015, 18, 49-59. [CrossRef] [PubMed]

16. Latella, D.; Maggio, M.G.; Maresca, G.; Saporoso, A.F.; Le Cause, M.; Manuli, A.; Milardi, D.; Bramanti, P.; De Luca, R.; Salvatore Calabrò, R. Impulse control disorders in Parkinson's disease: A systematic review on risk factors and pathophysiology. J. Neurol. Sci. 2019, 398, 101-106. [CrossRef]

17. Grall-Bronnec, M.; Victorri-Vigneau, C.; Donnio, Y.; Leboucher, J.; Rousselet, M.; Thiabaud, E.; Zreika, N.; Derkinderen, P.; Challet-Bouju, G. Dopamine Agonists and Impulse Control Disorders: A Complex Association. Drug Saf. $2018,41,19-75$. [CrossRef]

18. American Psychiatric Association. Diagnostic and Statistical Manual of Mental Disorders, 5th ed.; APA: Washington, DC, USA, 2013.

19. Ambermoon, P.; Carter, A.; Hall, W.D.; Dissanayaka, N.N.; O'Sullivan, J.D. Impulse control disorders in patients with Parkinson's disease receiving dopamine replacement therapy: Evidence and implications for the addictions field. Addiction 2011, 106, 283-293. [CrossRef]

20. Ben-Joseph, A.; Marshall, C.R.; Lees, A.J.; Noyce, A.J. Ethnic Variation in the Manifestation of Parkinson's Disease: A Narrative Review. J. Parkinsons Dis. 2020, 10, 31-45. [CrossRef]

21. Ávila, A.; Cardona, X.; Bello, J.; Maho, P.; Sastre, F.; Martín-Baranera, M. Impulse control disorders and punding in Parkinson's disease: The need for a structured interview. Neurología 2011, 26, 166-172. [CrossRef]

22. Ceravolo, R.; Frosini, D.; Rossi, C.; Bonuccelli, U. Impulse control disorders in Parkinson's disease: Definition, epidemiology, risk factors, neurobiology and management. Parkinsonism Relat. Disord. 2009, 15 (Suppl. 4), S111-S115. [CrossRef] 
23. Sáez-Francàs, N.; Martí Andrés, G.; Ramírez, N.; de Fàbregues, O.; Álvarez-Sabín, J.; Casas, M.; Hernández-Vara, J. Clinical and psychopathological factors associated with impulse control disorders in Parkinson's disease. Neurología 2016, 31, 231-238. [CrossRef] [PubMed]

24. Weintraub, D.; Koester, J.; Potenza, M.N.; Siderowf, A.D.; Stacy, M.; Voon, V.; Whetteckey, J.; Wunderlich, G.R.; Lang, A.E. Impulse control disorders in Parkinson disease: A cross-sectional study of 3090 patients. Arch. Neurol. 2010, 67, 589-595. [CrossRef] [PubMed]

25. Voon, V.; Fox, S.H. Medication-related impulse control and repetitive behaviors in Parkinson disease. Arch. Neurol. 2007, 64, 1089-1096. [CrossRef]

26. Ahlskog, J.E. Pathological behaviors provoked by dopamine agonist therapy of Parkinson's disease. Physiol. Behav. 2011, 104, 168-172. [CrossRef]

27. Seeman, P. Parkinson's disease treatment may cause impulse-control disorder via dopamine D3 receptors. Synapse 2015, 69, 183-189. [CrossRef]

28. Eimeren, T.; Ballanger, B.; Pellecchia, G.; Miyasaki, J.M.; Lang, A.E.; Strafella, A.P. Dopamine agonists diminish value sensitivity of the orbitofrontal cortex: A trigger for pathological gambling in Parkinson's disease? Neuropsychopharmacology 2009, 34, 2758-2766. [CrossRef]

29. Marques, A.; Durif, F.; Fernagut, P.O. Impulse control disorders in Parkinson's disease. J. Neural Transm. 2018, 125, 1299-1312. [CrossRef] [PubMed]

30. Atmaca, M. Drug-induced impulse control disorders: A review. Curr. Clin. Pharmacol. 2014, 9, 70-74. [CrossRef]

31. Voon, V.; Hassan, K.; Zurowski, M.; de Souza, M.; Thomsen, T.; Fox, S.; Lang, A.E.; Miyasaki, J. Prevalence of repetitive and reward-seeking behaviors in Parkinson disease. Neurology 2006, 67, 1254-1257. [CrossRef]

32. Weintraub, D.; Potenza, M.N. Impulse control disorders in Parkinson's disease. Curr. Neurol. Neurosci. Rep. 2006, 6, 302-306. [CrossRef] [PubMed]

33. Molina, J.A.; Sáinz-Artiga, M.J.; Fraile, A.; Jiménez-Jiménez, F.J.; Villanueva, C.; Ortí-Pareja, M.; Bermejo, F. Pathologic gambling in Parkinson's disease: A behavioral manifestation of pharmacologic treatment? Mov. Disord. 2000, 15, 869-872. [CrossRef]

34. Gallagher, D.A.; O'Sullivan, S.S.; Evans, A.H.; Lees, A.J.; Schrag, A. Pathological gambling in Parkinson's disease: Risk factors and differences from dopamine dysregulation. An analysis of published case series. Mov. Disord. 2007, 22, 1757-1763. [CrossRef] [PubMed]

35. Aarts, E.; Helmich, R.C.; Janssen, M.J.; Oyen, W.J.; Bloem, B.R.; Cools, R. Aberrant reward processing in Parkinson's disease is associated with dopamine cell loss. Neuroimage 2012, 59, 3339-3346. [CrossRef] [PubMed]

36. Al-Khaled, M.; Heldmann, M.; Bolstorff, I.; Hagenah, J.; Münte, T.F. Intertemporal choice in Parkinson's disease and restless legs syndrome. Parkinsonism Relat. Disord. 2015, 21, 1330-1335. [CrossRef] [PubMed]

37. Drew, D.S.; Muhammed, K.; Baig, F. Dopamine and reward hypersensitivity in Parkinson's disease with impulse control disorder. Brain 2020, 143, 2502-2518. [CrossRef]

38. Nirenberg, M.J.; Waters, C. Compulsive eating and weight gain related to dopamine agonist use. Mov. Disord. 2006, 21, 524-529. [CrossRef]

39. Joutsa, J.; Martikainen, K.; Vahlberg, T.; Voon, V.; Kaasinen, V. Impulse control disorders and depression in Finnish patients with Parkinson's disease. Parkinsonism Relat. Disord. 2012, 18, 155-160. [CrossRef]

40. Limotai, N.; Oyama, G.; Go, C.; Bernal, O.; Ong, T.; Moum, S.J.; Bhidayasiri, R.; Foote, K.D.; Bowers, D.; Ward, H.; et al. Addiction-like manifestations and Parkinson's disease: A large single center 9-year experience. Int. J. Neurosci. 2012, 122, 145-153. [CrossRef] [PubMed]

41. Poletti, M.; Logi, C.; Lucetti, C.; Del Dotto, P.; Baldacci, F.; Vergallo, A.; Ulivi, M.; Del Sarto, S.; Rossi, G.; Ceravolo, R.; et al. A single-center, cross-sectional prevalence study of impulse control disorders in Parkinson disease: Association with dopaminergic drugs. J. Clin. Psychopharmacol. 2013, 33, 691-694. [CrossRef]

42. Giladi, N.; Weitzman, N.; Schreiber, S.; Shabtai, H.; Peretz, C. New onset heightened interest or drive for gambling, shopping, eating or sexual activity in patients with Parkinson's disease: The role of dopamine agonist treatment and age at motor symptoms onset. J. Psychopharmacol. 2007, 21, 501-506. [CrossRef]

43. Claassen, D.O.; van den Wildenberg, W.P.; Harrison, M.B.; van Wouwe, N.C.; Kanoff, K.; Neimat, J.S.; Wylie, S.A. Proficient motor impulse control in Parkinson disease patients with impulsive and compulsive behaviors. Pharmacol. Biochem. Behav. 2015, 129, 19-25. [CrossRef]

44. Shotbolt, P.; Moriarty, J.; Costello, A.; Jha, A.; David, A.; Ashkan, K.; Samuel, M. Relationships between deep brain stimulation and impulse control disorders in Parkinson's disease, with a literature review. Parkinsonism Relat. Disord. 2012, 18, 10-16. [CrossRef]

45. Lee, J.Y.; Kim, J.M.; Kim, J.W.; Cho, J.; Lee, W.Y.; Kim, H.J.; Jeon, B.S. Association between the dose of dopaminergic medication and the behavioral disturbances in Parkinson disease. Parkinsonism Relat. Disord. 2010, 16, 202-207. [CrossRef]

46. Nakum, S.; Cavanna, A.E. The prevalence and clinical characteristics of hypersexuality in patients with Parkinson's disease following dopaminergic therapy: A systematic literature review. Parkinsonism Relat. Disord. 2016, 25, 10-16. [CrossRef] [PubMed]

47. Zahodne, L.B.; Susatia, F.; Bowers, D. Binge eating in Parkinson's disease: Prevalence, correlates and the contribution of deep brain stimulation. J. Neuropsychiatry Clin. Neurosci. 2011, 23, 56-62. [CrossRef] [PubMed]

48. Merola, A.; Romagnolo, A.; Rizzi, L. Impulse control behaviors and subthalamic deep brain stimulation in Parkinson disease. J. Neurol. 2017, 264, 40-48. [CrossRef] [PubMed] 
49. Gatto, E.M.; Aldinio, V. Impulse Control Disorders in Parkinson's Disease. A Brief and Comprehensive Review. Front. Neurol. 2019, 10, 351. [CrossRef] [PubMed]

50. Poewe, W.; Seppi, K.; Tanner, C.M. Parkinson disease. Nat. Rev. Dis. Primers 2017, 3, 17013. [CrossRef]

51. Callesen, M.B.; Weintraub, D.; Damholdt, M.F.; Møller, A. Impulsive and compulsive behaviors among Danish patients with Parkinson's disease: Prevalence, depression, and personality. Parkinsonism Relat. Disord. 2014, 20, 22-26. [CrossRef]

52. Crockford, D.; Quickfall, J.; Currie, S.; Furtado, S.; Suchowersky, O.; El-Guebaly, N. Prevalence of problem and pathological gambling in Parkinson's disease. J. Gambl. Stud. 2008, 24, 411-422. [CrossRef] [PubMed]

53. Garcia-Ruiz, P.J.; Martinez Castrillo, J.C.; Alonso-Canovas, A.; Herranz Barcenas, A.; Vela, L.; Sanchez Alonso, P.; Mata, M.; Olmedilla Gonzalez, N.; Mahillo Fernandez, I. Impulse control disorder in patients with Parkinson's disease under dopamine agonist therapy: A multicentre study. J. Neurol. Neurosurg. Psychiatry 2014, 85, 840-844. [CrossRef] [PubMed]

54. Ramírez Gómez, C.C.; Serrano Dueñas, M.; Bernal, O.; Araoz, N.; Sáenz Farret, M.; Aldinio, V.; Montilla, V.; Micheli, F. A Multicenter Comparative Study of Impulse Control Disorder in Latin American Patients with Parkinson Disease. Clin. Neuropharmacol. 2017, 40, 51-55. [CrossRef]

55. Kim, J.; Kim, M.; Kwon, D.Y.; Seo, W.K.; Kim, J.H.; Baik, J.S.; Koh, S.B. Clinical characteristics of impulse control and repetitive behavior disorders in Parkinson's disease. J. Neurol. 2013, 260, 429-437. [CrossRef] [PubMed]

56. Vallelunga, A.; Flaibani, R.; Formento-Dojot, P.; Biundo, R.; Facchini, S.; Antonini, A. Role of genetic polymorphisms of the dopaminergic system in Parkinson's disease patients with impulse control disorders. Parkinsonism Relat. Disord. 2012, 18, 397-399. [CrossRef]

57. Kim, Y.E.; Kim, H.J.; Lee, J.Y.; Yun, J.Y.; Kim, J.Y.; Paek, S.H.; Jeon, B.S. Impulse control and related behaviors after bilateral subthalamic stimulation in patients with Parkinson's disease. J. Clin. Neurosci. 2013, 20, 964-969. [CrossRef]

58. Hassan, A.; Bower, J.H.; Kumar, N.; Matsumoto, J.Y.; Fealey, R.D.; Josephs, K.A.; Ahlskog, J.E. Dopamine agonist-triggered pathological behaviors: Surveillance in the PD clinic reveals high frequencies. Parkinsonism Relat. Disord. 2011, 17, 260-264. [CrossRef]

59. Bastiaens, J.; Dorfman, B.J.; Christos, P.J.; Nirenberg, M.J. Prospective cohort study of impulse control disorders in Parkinson's disease. Mov. Disord. 2013, 28, 327-333. [CrossRef]

60. Perez-Lloret, S.; Rey, M.V.; Fabre, N. Prevalence and Pharmacological Factors Associated With Impulse-Control Disorder Symptoms in Patients With Parkinson Disease. Clin. Neuropharmacol. 2012, 35, 261-265. [CrossRef]

61. Antonini, A.; Cilia, R. Behavioural Adverse Effects of Dopaminergic Treatments in Parkinson's Disease. Drug Saf. 2009, 32, 475-488. [CrossRef]

62. Weintraub, D.; Siderowf, A.D.; Potenza, M.N.; Goveas, J.; Morales, K.H.; Duda, J.E.; Moberg, P.J.; Stern, M.B. Association of dopamine agonist use with impulse control disorders in Parkinson disease. Arch. Neurol. 2006, 63, 969-973. [CrossRef]

63. Solla, P.; Cannas, A.; Floris, G.L.; Orofino, G.; Costantino, E.; Boi, A.; Serra, C.; Marrosu, M.G.; Marrosu, F. Behavioral, neuropsychiatric and cognitive disorders in Parkinson's disease patients with and without motor complications. Prog. Neuropsychopharmacol. Biol. Psychiatry 2011, 35, 1009-1013. [CrossRef]

64. Rana, A.Q.; Mansoor, W.; Hussaini, S.; Al Mosabbir, A.; Rahman, M.; Rahman, L. Factors associated with the development of impulse compulsive disorders in Parkinson patients. Int. J. Neurosci. 2013, 123, 503-506. [CrossRef] [PubMed]

65. Politis, M.; Loane, C.; Wu, K.; O’Sullivan, S.S.; Woodhead, Z.; Kiferle, L.; Lawrence, A.D.; Lees, A.J.; Piccini, P. Neural response to visual sexual cues in dopamine treatment-linked hypersexuality in Parkinson's disease. Brain 2013, 136 Pt 2, 400-411. [CrossRef] [PubMed]

66. Valença, G.T.; Glass, P.G.; Negreiros, N.N.; Duarte, M.B.; Ventura, L.M.; Mueller, M.; Oliveira-Filho, J. Past smoking and current dopamine agonist use show an independent and dose-dependent association with impulse control disorders in Parkinson's disease. Parkinsonism Relat. Disord. 2013, 19, 698-700. [CrossRef] [PubMed]

67. Moore, T.J.; Glenmullen, J.; Mattison, D.R. Reports of pathological gambling, hypersexuality, and compulsive shopping associated with dopamine receptor agonist drugs. JAMA Intern. Med. 2014, 174, 1930-1933. [CrossRef]

68. Vela, L.; Martínez Castrillo, J.C.; García Ruiz, P.; Gasca-Salas, C.; Macías, Y.; Pérez Fernández, E.; Ybot, I.; Lopez Valdés, E.; Kurtis, M.M.; Posada Rodriguez, I.J.; et al. The high prevalence of impulse control behaviors in patients with early-onset Parkinson's disease: A cross-sectional multicenter study. J. Neurol. Sci. 2016, 368, 150-154. [CrossRef]

69. Leroi, I.; Andrews, M.; McDonald, K.; Harbishettar, V.; Elliott, R.; Byrne, E.J.; Burns, A. Apathy and impulse control disorders in Parkinson's disease: A direct comparison. Parkinsonism Relat. Disord. 2012, 18, 198-203. [CrossRef]

70. Obeso, J.A.; Stamelou, M.; Goetz, C.G. Past, present, and future of Parkinson's disease: A special essay on the 200th Anniversary of the Shaking Palsy. Mov. Disord. 2017, 32, 1264-1310. [CrossRef] 